\title{
"With the Name Changed, the Story Applies to You!": Connections between Slavery and "Free" Labor in the Writings of Marx
}

\author{
Pepijn Brandon
}

The field of Global Labor History that Marcel van der Linden more than anyone helped to develop, rests - among other elements - on the rejection of the idea that capitalism and "free" wage labor go hand in hand. This rejection entails a critique on both Marxian and Weberian approaches to labor history. ${ }^{1}$ It forms a major challenge to the theoretical framework of classical political economy in which "free" labor holds an important place. This was true for the founders of classical liberalism as well as for Marx, although they started from different theoretical assumptions and drew completely opposite political conclusions. Of these two, it is Marx who forms the real starting point for Van der Linden's reconceptualization. In Van der Linden's view, Marx's analysis of capitalist development is at one and the same time "still the best we have," but also one that contains serious "limitations, errors and immanent contradictions." In an act of self-conscious heterodoxy, Van der Linden expands Marx's notion of the centrality of commodified labor power to include forms of coerced labor that Marx explicitly excluded. This, he argues, is necessary for understanding capitalism's past and its future. It forms the basis for a truly global labor history that acknowledges the many intermediary forms between plantation slavery as the most extreme form of coerced labor, and an idealized version of "free" wage labor, that have operated under the control of capital. Recognizing such intermediary forms is of special relevance for understanding the history of capitalism in colonial and post-colonial contexts. However, it also has important consequences for understanding capitalism in the West, where

1 Marcel van der Linden and Jan Lucassen, Prolegomena for a Global Labor History (Amsterdam, 1999), 6.

2 Marcel van der Linden, Workers of the World. Essays towards a Global Labor History (Leiden and Boston, 2008), 18; Marcel van der Linden and Karl Heinz Roth, "Introduction," in Beyond Marx. Theorising the global labour relations of the twenty-first century, eds. Marcel van der Linden and Karl Heinz Roth (Leiden and Boston, 2014), 1-20, 7.

(C) PEPIJN BRANDON, 2018 | DOI:10.1163/9789004386617_004 
unpaid, non-industrial, and precarious labor have always remained an important element of labor relations. Furthermore, it is crucial for understanding why coerced labor persists on a large scale in the present, while capitalism has expanded to every corner of the world. ${ }^{3}$

As could be expected, Van der Linden's critique of Marx's approach to wage labor prompted much debate among Marxist scholars. ${ }^{4}$ Regardless of the way in which one judges the merits of the underlying theoretical argument, there is no doubt that the research program launched as a result of it has opened up important new areas for the study of labor and class struggle under capitalism. ${ }^{5}$ In this article, I do not engage with the latter topic. Instead, I focus on a paradox in Marx's work that in my view partially helps to better position the subject of Van der Linden's critique, and partially allows for the kind of heterodox rereading that he proposes. The paradox is that in the same period in which Marx strengthened and refined his analysis of the centrality of "free" wage labor to the capitalist mode of production, he also started to put greater emphasis on the parallels and historical connections between slavery and "free" wage labor. This is shown most explicitly in a famous passage on the lengthening of the working day in Capital, Volume I. Marx extensively cites the American writer J.E. Cairnes's The Slave Power on the way in which slaveholders who have access to a steady supply of new slave laborers work their slaves to death "durch die langsame Tortur von Ueberarbeit und Mangel an Schlaf und Erhohlung" [through the slow torture of overwork and lack of sleep and fare]. ${ }^{6}$

3 Van der Linden, Workers of the world, 19-20.

4 Two recent discussions of the implications of Van der Linden's re-interpretation for our understanding of Capital (the first highly critical, the second much more sympathetic to his approach) are Alex Callinicos, Deciphering Capital. Marx's Capital and its destiny (London, 2014), 197-211, and Massimiliano Tomba, Marx's temporalities (Leiden and Boston, 2013), 149.

5 For examples of the breadth of scholarship stimulated by the Global Labor History approach pioneered by Van der Linden at different stages of the project, see Free and unfree labour. The debate continues, eds. Tom Brass and Marcel van der Linden (Bern etc., 1997); On coerced labor. Work and compulsion after chattel slavery, eds. Marcel van der Linden and Magaly Rodríguez García (Leiden and Boston, 2016).

6 Marx Engels Gesamt Ausgabe (MEGA $\left.{ }^{2}\right)$ II.5, 209. In my research for this article, I mainly used the Marx Engels Werke and the $M E G A^{2}$, the latter being the most complete and authoritative edition of his writings. This also allowed me to check for possible changes made by Marx between the first edition of Capital in German, quoted here, and later editions, particularly the French edition of 1875 (reprinted in $M E G A^{2}$ II.7), which is the edition that contains the most substantial changes by Marx himself. For the readers' convenience, I have replaced quotations in German with the standard translations from the Marx Engels Collected Works (London 1974-2001) [hereafter MECW]. However, even in this edition there are still significant differences between the German original and the English translation. The quoted passage above is a case in point. The German edition contained Marx's own (mis-)translation 
Marx then turns his attention directly to the recruitment of the "free" wage laborer for modern industry:

Mutato nomine de te fabula narratur! [With the name changed, the story applies to you!] For slave trade read labour market, for Kentucky and Virginia, Ireland and the agricultural districts of England, Scotland, and Wales, for Africa, Germany. We heard how overwork thinned the ranks of the bakers in London. Nevertheless, the London labour market is always overstocked with German and other candidates for death in the bakeries. $^{7}$

Based on a large number of passages in which Marx invokes slavery to talk about wage labor-not only in Capital, Volume I, but throughout his published and unpublished works, letters, notebooks, and drafts-I will show that this exclamation was not a rhetorical flourish. It expressed persistent attention to both the contrasts, and the connections and parallels between slavery and wage labor in Marx's work. This attention derived in a large part from the fact that for Marx, writing in the nineteenth century, slavery was not a historical problem, but a contemporary one. Interestingly enough, Marx's interest in this matter became more pronounced precisely at a time when real historical events-the abolition of serfdom in Russia and of slavery in North America - might easily have been taken by him as a confirmation of the necessary connection between capitalism and a linear progress toward "free" labor. Lastly, I argue that more than is often acknowledged, thinking about slavery played a role in the way Marx conceptualized wage labor itself, especially in helping him to draw a sharp line between his own, bracketed notion of "free" labor and that of liberal political economists. Such a reading is at odds with many orthodox interpretations of Marx's work, which one-sidedly stress Marx's reasons to contrast wage labor and slavery. Perhaps unexpectedly, the critique of Marx formulated by Van der Linden can thus open the way for a re-examination that reveals Marx himself as a much more nuanced thinker on the relationship between coerced labor and capitalism than is often assumed.

of Cairnes, which is considerably stronger in wording than Cairnes's original, to which the English edition logically reverted. Here, instead of "slow torture of overwork" it simply reads "unremitting toil," a difference that tells us something about Marx's intention in citing these lines. $M E C W$ 35, 272. Because of such differences, I maintain page references for the original citations taken from the $M E G A^{2}$ edition, and wherever needed, cite the German original either in the footnote or the body of the text.

7 MECW 35, 272 / MEGA2 II.5, 209. The Latin phrase is taken from Horace, Satires, Book I, Satire 1. 
It is easy to forget that for Marx, the question of slavery and its relationship to wage labor was a matter of contemporary politics. By the time Marx entered democratic politics in the early 1840 s, a strong sentiment against slavery and the slave trade had become highly influential among European liberal democrats. Slave revolts and abolitionist campaigns had firmly etched the image of cruelty inherent in slavery into public consciousness. However, at least with regard to elite perceptions, another key element of the success of anti-slavery campaigns was the conviction popularized by prominent political economists that under normal circumstances, wage labor would always prove more productive and therefore profitable than slave labor. Adam Smith had already expressed his belief, "that the work done by freemen comes cheaper in the end than that performed by slaves." 8 Referring to slavery in antiquity, James Steuart had drawn a less flattering contrast, but still one that stresses the independent agency of the wage worker: "Men were then forced to labour because they are slaves to others; men are now forced to labour because they are slaves to their own wants."9 Three-quarters of a century later, looking back on the abolition of both the slave trade and slavery in the British colonies, John Stuart Mill was able to write with some confidence: "The history of human improvement is the record of a struggle by which inch after inch of ground has been wrung from these maleficent powers, and more and more of human life rescued from the iniquitous dominion of the law of might."10 However, casting one's gaze a little wider, the nineteenth century did not look so bright. Slavery had rapidly expanded in the United States, Brazil, and Cuba. The possibilities of reopening the transatlantic slave trade were openly discussed in France in the late 1840 s. New forms of indentured and coerced labor developed in the colonies, while penal labor became a central plank of the punishment regime of European states. Meanwhile, the realities of factory labor in the heartlands of the industrial revolution proved to be very far from the rosy perceptions of freedom of the liberal theorists. ${ }^{11}$

Starting their political careers on the radical fringe of liberal democracy and rapidly moving into circles of working-class socialists, Marx and Engels were acutely aware of these contradictions. In The Poverty of Philosophy, one

8 Adam Smith, The wealth of nations. Books I-III (London, 1999 [1776]), 184.

9 James Steuart, An inquiry into the principles of political economy, vol. 1 (London, 1767), 40.

10 John Stuart Mill, "The Negro question" (1850), in The collected works of John Stuart Mill, vol. XXI, ed. John M. Robson (London, 1984).

11 For a broad overview and recent theorization of these developments, see Dale W. Tomich, Through the prism of slavery. Labor, capital, and the world economy (Lanham etc., 2004). 
of the first works in which Marx laid out his own economic theory in a polemic against the French anarchist Proudhon, Marx wrote that "direct slavery" in the Americas is "just as much the pivot of bourgeois industry as machinery, credits, etc. Without slavery you have no cotton; without cotton you have no modern industry."12 Marx clearly attached some weight to this argument, since he included it verbatim in an 1846 letter to P.W. Annenkow in which he summarizes his main criticisms of Proudhon. ${ }^{13}$ However it could be said that at this stage, Marx and Engels still approached slavery in the colonies from the same analytical distance from which they remarked on colonial developments in general. ${ }^{14}$ In relation to slavery, this can be seen in particular from Engels' incidental adoption of an argument with strong overtones of racism then current among sections of the labor movement, presenting wage labor as a "worse kind" of slavery than plantation slavery. This literal phrase can be found in the Condition of the Working Class in England..$^{15}$ In an article on the struggle by the British working class for the restriction of the working day to ten hours, Engels went as far as to claim that "the fate of the slaves in the worst of the American plantations was golden in comparison with that of the English workers in that period."16

Furthermore, as was shown most clearly in Marx's famous article on "the future of British rule in India," in the early 185 os both Marx and Engels still held the view that capitalist development would be the main instrument of historical progress in the colonial world, although unwittingly and at great human cost. From this point of view, colonial subjects or slaves figured as the passive victims of capitalist progress. In an article written jointly by Marx and Engels in 1850, the authors repeat Marx's earlier assertion that the "crucial sector of British

$12 \quad \operatorname{MECW} 6,167$.

13 Marx to P.W. Annenkow, 28 December 1846, $\operatorname{MEcW} 38$, 101.

14 Many writers have commented on this, especially in relation to Marx's early writings on India. For recent discussions, see Keven B. Anderson, Marx at the margins. On nationalism, ethnicity, and non-Western societies (Chicago and London, 2010), 11-17; Lucia Pradella, Globalization and the critique of Political Economy. New insights from Marx's writings (London and New York, 2014).

$15 \quad M E C W 2,468$.

$16 \operatorname{MECW} 10,291$. For an extensive discussion of the notions of "white slavery" and "wage slavery" in the contemporary labor movement, including its racist connotations, see David R. Roediger, The wages of whiteness. Race and the making of the American working class (London, 1991), 65-92. Of course, it would be ahistorical to measure these and other statements by Marx and Engels by the standards of twenty-first-century sensitivity to language use. Nevertheless, these quotations from Engels in particular show considerable ignorance or insensitivity about the actual conditions under which slaves in the Americas lived and worked. In important respects, this attitude changed in Marx's and Engels' later writings. 
industry" depended on slavery in the American South. After briefly speculating on the possibility of slave revolt, they argue that "the only feasible solution to the slave question" lay elsewhere:

As soon as the free labour of other countries provides industry with its cotton supplies in sufficient quantity and more cheaply than the slave labour of the United States, American slavery will have been broken at the same time as the American cotton monopoly, and the slaves will be emancipated because as slaves they will have become unusable. ${ }^{17}$

This mechanical view, in which plantation slavery and the slaves themselves figured abstractly and passively as the backdrop to dynamics that unfolded elsewhere, would be seriously revised by Marx in the course of the 185 os and early 186os. There were three main sources for this revision. The first was theoretical. After the defeat of the 1848-1849 revolutions, Marx decided to use the expected long lull in the class struggle to write his "critique of political economy": A task that he never managed to complete. ${ }^{18}$ Part of this gargantuan enterprise was to revise Ricardo's theory of ground rent, which—like for example the role of money and banking in a capitalist economy—presented significant theoretical problems for the labor theory of value. ${ }^{19}$ To strengthen the empirical basis for his arguments, Marx undertook serious studies on colonial land use, agricultural labor, and land prices, as well as on the history of colonization by European powers in general. ${ }^{20}$ The London Notebooks of $1850-1853$ that comprise the residue of the first of these efforts, contain many notes on slavery in European and non-European ancient empires, and in the European colonies and the U.S. ${ }^{21}$ The notes mainly consist of long extracts from the texts of others, sometimes literally transcribed, sometimes paraphrased in Marx's unique pidgin of several living and dead languages. They hardly give a clear roadmap to his thinking during this period. However, they do indicate that his interest in

$17 \quad M E C W 10,500-501$.

18 On Marx's reasons for this decision, see August H. Nimtz Jr., Marx and Engels. Their contribution to the democratic breakthrough (New York, 2000), 151-155.

19 Enrique Dussel, Towards an unknown Marx. A commentary on the Manuscripts of 1861-63 (London and New York, 2001), 82-83.

20 Pradella, Globalisation, 104-112.

21 Examples of the former are Marx's notes on Dureau de Lamalle, Économie politique des Romains and W.H. Prescott, History of the Conquest of Mexico, MEGA2 IV.9, 332, 335, 340, 406, 432. Examples of the latter are his copious notes on H.C. Carey, The Past, the present and the future, MEGA ${ }^{2}$ IV.8, 748-749, Herman Merivale, Lectures on colonization and colonies, $M E G A^{2}$ IV.9, 436-438, 442-448, 465-472, and Th.F. Buxton, The African slave trade, $M E G A^{2}$ IV.8, 494-498. 
slavery became more concrete and historical, and took into account the actual forms under which slavery prevailed in his own day. Among other topics, Marx paid attention to the great varieties of slavery that existed in different phases of human history, the enormous cost in terms of human life of the illegal slave trade, and the "Cultur der jealousy zwischen [Creoles] und den inferior or mixed races" in which "the place of a man in society was made to depend on his colour, even to the minutest shades."22

A second source for Marx's closer examination of the question of slavery was his growing engagement with colonialism. This found its clearest expression in his articles on China and India for the New York Tribune. Marx's large journalistic output of the 1850 os and early 1860 os was for a long time almost entirely ignored as a site of theoretical development. However, as Michael Krätke has argued, in these voluminous writings many topical questions relating to the operation of the capitalist system on an international scale were first developed. ${ }^{23}$ The Tribune had been founded in 1841 as "a crusading organ of progressive causes," among which abolitionism took pride of place. ${ }^{24}$ By the time he was recruited as its London correspondent in 1851, the Tribune had emerged as the biggest selling newspaper in the world, with more than 200,000 readers. $^{25}$ In its pages, Marx wrote with acerbic wit and great indignation about European colonialism. His greatest venom was reserved for British colonialism, which hid its brutal face behind liberal free-trade ideology. Given the importance of anti-slavery sentiments to Britain's humanitarian self-image, the way in which the global expansion of British trade continued to rely on-and even fostered-slavery while also creating misery at home, drew his special attention as proof of the hypocrisy underlying such claims. ${ }^{26}$ Meanwhile, the Sepoy uprising in India and the Taiping rebellion in China led Marx to consider rebellion of the colonial subjects themselves as an independent force in history, leading him to break with Eurocentric notions of historical progress. ${ }^{27}$

$22 M E G A^{2}$ IV.8, $567 ; M E G A^{2}$ IV.9, 495 , and 438 respectively. In the cited passage, Marx paraphrases Merivale.

23 Michael Krätke, "Journalisme et science. L'importance des travaux journalistiques de Marx pour la critique de l'économie politique," Actuel Marx, 42, no. 2 (2007): 128-163, 129.

24 James Ledbetter, "Introduction," in Karl Marx, Dispatches for the New York Tribune. Selected journalism of Karl Marx, ed. James Ledbetter (London, 2007), xvii-xxvii, xvii.

25 James Ledbetter, "Introduction," in Karl Marx, Dispatches for the New York Tribune. Selected journalism of Karl Marx, ed. James Ledbetter (London, 2007), xviii.

26 E.g. "The Duchess of Sutherland and slavery," in Marx, Dispatches, 113-119; "The British government and the slave-trade," in Marx, Dispatches, 261-266; "The British cotton trade," in Marx, Dispatches, 276-280.

27 Anderson, Margins, 38; Lucia Pradella, "Marx and the Global South. Connecting history and value theory," Sociology, 51, no.1 (2017): 146-161. Marx's turn away from Eurocentric 
However, by far the most important determinant of the place slavery would be given in Marx's economic studies of the 186os was the American Civil War. Marx's writings of this period show the extent of his emotional, intellectual, and practical investment in the support for the North. ${ }^{28}$ Long before Lincoln's Emancipation Act, at the very start of the conflict between the Confederacy and the Union, Marx insisted on the centrality of slavery as the key issue at stake. In an article written for the Vienna-based liberal newspaper Die Presse, he described the war as "nothing but a struggle between two social systems, the system of slavery and the system of free labour."29 However, Marx no longer believed that the development of free trade or the proliferation of free labor would in itself solve this clash in favor of the latter. In line with his journalistic critique of British colonialism, he insisted that English trade interests led British industrialists to give full support to the South. He therefore saw it as a core task of the British and international working-class movement to oppose any move toward European intervention in support of the slaveholding states. The foundation of the International Workingmen's Association provided Marx with an opportunity to engage in practical agitation in support of the North. ${ }^{30}$ Through his writings for the Tribune, and later through his connections with German revolutionary émigrés, Marx consistently stressed the need to revolutionize the war effort. ${ }^{31}$ His confidence in the ultimate victory of the North, not always shared by his associate Engels, relied in a large part on his conviction

notions of progress would deepen in the 1870 s and early 1880 s, when he undertook major studies in Russian and Indian agricultural development to consider the various routes capitalist development could take. Tomba, Temporalities, 170-178.

28 This investment was shared by the entire Marx household. In December 1863, Marx's then eight-year-old daughter Eleanor wrote to her uncle Lion Philips, whom she had never met: "Do you like A.B. [Abe Lincoln]? He is a big friend of mine." "Was ik maar weer in Bommel." Karl Marx en zijn Nederlandse verwanten, ed. Jan Gielkens (Amsterdam, 1997), 109. Wilhelm Backhaus has argued, though in my view not entirely convincingly, that Marx's and Engels' political investment in abolitionism was so strong that it led them to considerable misreading — to the point of conscious misrepresentation—of the evidence concerning the economic viability of slavery in the Southern states. According to Backhaus, they even projected this evidence backwards onto slavery in classical antiquity. Wilhelm Backhaus, Marx, Engels und die Sklaverei (Düsseldorf, 1974), 248.

$29 M E C W$ 19, 50.

30 Robin Blackburn, An unfinished revolution. Karl Marx and Abraham Lincoln (London and New York, 2011), 46-49.

31 The most important of these connections was Joseph Wedemeyer, a veteran of the revolution of 1848 who became a technical aide on the staff of the Northern General John C. Frémont. August H. Nimtz, Jr., Marx, Tocqueville, and race in America. The "Absolute Democracy" or "Defiled Republic" (Lanham etc., 2003), 118-129. 
that emancipation would boost the Northern war effort. ${ }^{32}$ This heightened his attention to the revolutionary potential of the activity of the slaves. Marx had already written to Engels in 1860, in the wake of John Brown's famous attempt to trigger a general slave revolt by an armed raid on Harpers Ferry:

In my view, the most momentous thing happening in the world today is the slave movement — on the one hand, in America, started by the death of Brown, and in Russia, on the other ... Thus, a "social" movement has been started both in the West and in the East ... This promises great things. ${ }^{33}$

The conflict in North America accompanied Marx for the entire period during which he transformed his earlier drafts into Capital, Volume I. It sealed the process in which, for Marx, slavery changed from one of the many distant grievances that would be violently shoved aside by the juggernaut of capitalist development, to the locus of concrete struggles intimately connected to those of the international working class. Writing to François Lafargue, the child of a Caribbean mixed relationship and father of his later son-in-law Paul Lafargue, Marx coined a phrase that would also find its way into Capital: "le travail, tant qu'il est flétri dans la peau noire, ne sera jamais émancipé dans la peau blanche" [labor in white skin will never be emancipated, where in black skin it is branded]. ${ }^{34}$

\section{Wage Labor and Capital}

To understand the influence that Marx's developing insights had on the way he refers to slavery in his mature work, it is necessary to briefly discuss why, and how, Marx saw wage labor as central to capitalism. As is well known, during 1842 and 1843 the young Marx turned away from philosophy and toward the working class as the leading force for the emancipation of mankind. ${ }^{35}$

32 Nimtz, Jr., Marx, Tocqueville, and race in America, 104-110.

33 Marx to Engels, 11 January 186o, MECW 41, 4.

34 Marx to François Lafargue, 12 November 1866, Marx Engels Correspondance, VIII (Paris, 1981) (French original). The English translation given in $M E C W 42,334$ considerably tones down Marx's phrase, leaving out the references to both skin and branding. The French version in this letter matches the German version of the same remark in Capital, vol. I. $M E G A^{2}$ II.5, 239-240.

35 Shlomo Avineri, The social and political thought of Karl Marx (Cambridge, 1968), 41-64; Hal Draper, Karl Marx's theory of revolution, vol. II: The politics of social classes (New York, 1978), 33-48. 
In the light of the critique of Marx's privileging of the working class formulated by Global Labor History, it deserves emphasis that through this turn, Marx primarily distanced himself from those who looked to sections of the middle class (the philosophers, philanthropists, utopian thinkers, and social improvers) as the agents of social change. ${ }^{36}$ Marx's shift rested on a perception of the working class as a "universal class" or a "class for all classes," distinct from, but interested in and connected to the struggles of all the other subaltern groups. The proletariat was envisioned as the social sphere "which cannot emancipate itself without emancipating itself from all other spheres of society and thereby emancipating all other spheres of society, which, in a word, is the complete loss of man and hence can win itself only through the complete rewinning of man."37 Marx's studies of political economy would soon lead him to define the relationship between the working class and the other social classes in less philosophical terms. Without losing the broad emancipatory thrust of his earlier writings, he increasingly focused on the special role of the exploitation of wage labor in capitalist production. ${ }^{38}$

From his preparatory work for the Grundrisse to the publication of Capital, Volume I, Marx fundamentally reworked the main concepts of classical political economy. ${ }^{39}$ In the process, he would also fundamentally deepen his analysis of the mechanisms through which wage labor is tied to capital. Nevertheless, in a more rudimentary form, the different elements for understanding this dependency had already been outlined as early as $1847 .^{40}$ Marx did this in a short text titled Wage Labour and Capital, which was initially conceived as a series of lectures to the Brussels workers' association and then published in the Neue Rheinische Zeitung two years later. It came well before the crucial break in Marx's understanding of the categories that he inherited from classical economy: His "discovery" that the worker sells to the capitalist not labor, but labor

36 Michael Löwy, The theory of revolution in the young Marx (Leiden and Boston, 2003), 23-61.

$37 \quad M E C W$ 3, 186. The German original does not speak of man, but of der Mensch. MECW 1, 390.

38 Enrique Dussel shows the continued presence of what he calls an "ethics of liberation" in Marx's project to revise political economy. Enrique Dussel, La producción teórica de Marx. Un comentario a los Grundrisse (Madrid etc., 1985), 355.

39 For the development of Marx's concepts, see V.S. Vygodski, The story of a great discovery. How Karl Marx wrote "Capital" (Berlin, 1973); Roman Rosdolsky, The making of Marx's Capital (London, 1977). For an accessible recent summary of the theoretical issues at stake, see Michael Heinrich, An introduction to the three volumes of Karl Marx's Capital (New York, 2004). 
power. ${ }^{41}$ Even so, Marx's treatment of the necessary relationship between capital and wage labor in this early text provides an excellent starting point from which to understand the later development of his thoughts. Significantly for the theme of this article, the discussion begins with an allusion to slavery. The context of this passage is an argument over whether capital is simply any collection of raw materials, work instruments, or consumption goods-as it is in a "production factors" approach —or, as Marx argued, that such commodities only become capital as a result of their function within a definite set of social relations.

What is a Negro slave? A man of the black race. The one explanation is as good as the other. A Negro is a Negro. He only becomes a slave in certain relations. A cotton-spinning jenny is a machine for spinning cotton. It becomes capital only in certain relations. ${ }^{42}$

According to Marx, what changes a collection of commodities ("dead labor") into capital, is that it is posited (through market exchange) as a social power that dominates over, and reproduces itself through, the employment of commodified labor (later: Labor power). This brings into a necessary relation four different moments: (1) The moment of the sale of labor (labor power); (2) the

41 This is the cornerstone of Marx's explanation for the specific form taken by exploitation under capitalism. Both Adam Smith and David Ricardo grappled with a fundamental question: (1) if labor is the source of all wealth, (2) if we assume all market exchanges take place at their value, and (3) if capitalists buy labor from the workers at its value too, then where does the capitalist's profit come from? The only solution seems to be to either assume that profits are a wage for the capitalist's own labor (abandoning the fundamental distinction between profit and wage that political economy aims to explain in the first place), or to assume that profits arise from the market exchange of commodities at prices that have no inherent relation to the amount of labor they contain (abandoning the labor theory of value that formed the starting point for political economy), or to assume that under capitalism, labor is always bought at a wage that is lower than its actual value (effectively saying that no profits are possible under "average conditions"). Marx's solution is as simple as it is effective. Capitalists do not buy labor at all. They buy labor power for a certain amount of time, the "use value" of which is that it adds labor as the substance of value to the commodity during the time in which it is employed in the process of production. Paying a wage entitles the capitalist to ownership of the products produced by the use value of "labor power" during this entire period, regardless of the actual amount of "congealed labor" they contain. This makes it possible to explain the existence of a "surplus value" of unpaid labor by the worker, without abandoning either the labor theory of value or the theoretical starting-point of average exchange at prices that correspond to value. For a more complete explanation, see Rosdolsky, Making, 194-211, or Heinrich, Introduction. 
process of production during which the laborer produces for capital; (3) the privatized moment of consumption through which the laborer has to expend the wage previously earned in order to "reproduce" him or herself (and his or her family); (4) forcing him or her to re-enter the labor market and allow for a new cycle of production. Marx continues to explain why this necessary relationship between the different moments constitutes the basis for the capitalist form of social domination. Capital becomes capital only in its relation to "a class which possesses nothing but its capacity to labour." ${ }^{33}$ And it is this lack of any other options than to sell his or her labor power that turns the ostensibly "free" act of sale on the part of the laborer into an act of social subjection of the worker to capital as an alien force. ${ }^{44}$

One of the interesting aspects of this argument is that already at this early stage, Marx emphasized the circular nature of capitalist production. While producing commodities, it also reproduces the preconditions for its own continued existence. In this process, the subjection of the laborer is expansive and necessarily engulfs the "free" act of sale of labor power itself. In Marx's words:

Does a worker in a cotton factory produce merely cotton textiles? No, he produces capital. He produces values which serve afresh to command his labour and by means of it to create new values. Capital can only increase by exchanging itself for labour [power], by calling wage labour to life. The wage labour [The labour power of the wage-worker] can only be exchanged for capital by increasing capital, by strengthening the power whose slave it is. Hence, increase of capital is increase of the proletariat, that is, of the working class. ${ }^{45}$

In this early text, not only does Marx already present in a very rough form the integrated levels on which he would follow the relationship between wage labor and capital in the three volumes of Capital (production, circulation, total

$43 \quad$ MECW 9, 213.

44 The notion that the worker's labor is "forced labor" because it only serves "to satisfy needs external to it" was already present in the Manuscripts of 1844. See Michael A. Lebowitz, Beyond Capital. Marx's political economy of the working class (London, 1992), 21. Also see the perceptive discussion of the relationship between (un)freedom, needs, and wants in Frédéric Lordon, Willing slaves of capital. Spinoza and Marx on desire (London and New York, 2014). Marcel van der Linden agrees with this categorization, and therefore includes wage labor in his taxonomy of coerced labor. Marcel van der Linden, "Dissecting coerced labor," in Van der Linden and Rodríguez García, On coerced labor, 293-322, 295.

$45 \quad M E C W$ 9, 214. The words in brackets denote the changes made by Engels in the 1891 edition, to account for Marx's later point of view. 
social reproduction), but the passage these quotations are taken from also contains a peculiar shift in the use of the concept of "slavery," which Marx would continue to employ in Capital. In the first quotation, slavery is invoked to underline that economic phenomena such as slavery or capital only attain their meaning under specific social relations. However, only a few pages later Marx states that the wage laborer is - not is like, or seems to be - the slave of capital. The easy way out of this conundrum would be to say that slavery in its first use refers to actual, historical slavery, whereas in its second use it should only be understood abstractly or rhetorically, but this is not the case. As we have seen previously, underlying all Marx's references to slavery in this period was a detached and to some extent a-historical notion of the actual slavery of his time. On the other hand, his growing political engagement with and historical interest in actual slavery did not persuade him to stop drawing direct parallels between the wage laborer and the slave. On the contrary, it would lead him to do so at a far greater level of concreteness.

\section{Slavery and the Boundaries of the Workers' "double freedom"}

In Capital, Volume 1, Marx argues that capital can only reproduce itself when it encounters the "free" laborer on the market. Marx famously defines this freedom in a "double sense": "that as a free man he can dispose of his labour power as his own commodity, and that on the other hand he has no other commodity for sale, is short of everything necessary for the realisation of his labour power." 46 Summarizing, the first half of this duality denotes the freedom of the laborer to sell his or her labor power, the second the "freedom from alternatives" that forces him or her to actually do so. Jairus Banaji formulated a devastating critique of attempts to ascribe to Marx the notion that this "freedom" of the wage laborer is at the same time both "formal" and "positive." Such an interpretation of the nature of "free labor" was essential to the approach of classical liberalism. In contrast to his theoretical opponents, Marx's "references to free labour have a profoundly delegitimating intent." ${ }^{27}$ Comparing wage labor to slavery plays an important role in bringing out this purpose. It is one of the key markers by which Marx distinguishes his own approach to free labor from that

$46 \quad M E C W$ 35, $179 / M E G A^{2}$ II.5, 122.

47 Jairus Banaji, Theory as history. Essays on modes of production and exploitation (Leiden and Boston, 2010), 137. On the liberal interpretation of free labor, see Robert J. Steinfeld, The invention of free labor. The employment relation in English and American law and culture, 1350-1870 (London: Chapel Hill, 1991), 147-148. 
of authors such as Adam Smith, James Steuart, or John Stuart Mill, quoted in the first section of this article.

The delegitimization of the notion of the "free" wage laborer in Marx goes in three directions, each of which was already present in the earlier Wage Labour and Capital. First, freedom is emphatically restricted to the sphere of circulation where the capitalist buys the labor power of the wage worker. Once the act of sale is completed, and for the full duration for which the sale is concluded, the laborer is legally bound to the capitalist. Liberal writers thought that such "temporary, voluntary subjection" did not cancel out the freedom of those engaging in it. ${ }^{48}$ However, as the designation of the laborer as the "slave" of capital in Wage Labour and Capital already shows, Marx thought it did. According to him, the relationship between the capitalist and the worker during the production process was not one of an equal interaction between two free agents, but one of "despotism." ${ }^{49}$ Furthermore, as is the case in slavery, the function of this despotism is to minimize the time in which the laborer produces the necessary goods (or their equivalent in money) for his or her own upkeep and that of the family, and to maximize the time worked "for nothing" for the master/employer. ${ }^{50}$ Clearly, it is in the derivation of surplus value from unpaid labor performed in the sphere of production that the historical connection with slavery and other forms of coerced labor runs deepest. Second, Marx only saw the sale of labor power in the process of circulation itself as a voluntary act in a very limited sense. This goes to the heart of his notion of double freedom, in which the second leg of this duality posits an ironic commentary on the first. Whereas the free disposal over one's own labor power can still be construed as a positive freedom in the liberal sense, the "freedom" from means of existence or employment outside the capital relation that complements it is purely negative. This "freedom" is not a constrained freedom. It is itself a constraint, which leaves the worker no other choice than to sell his or her labor power. Last, this force operates not just on an individual scale, in the relationship between capitalist and worker that is mediated through the market, but on a social scale. The apparent freedom granted by the market to

\footnotetext{
48 Steinfeld, Invention, 148.

$49 \quad M E C W 35,362$.

50 Marx already emphasized the resulting change in the form of exploitation in his Мanuscripts of 1861-1863, "The money relation, the sale and purchase between worker and capitalist, disguises the former's labour for no return, whereas with slave labour the property relation of the slave to his master disguises the former's labour for himself." MECW 34, 98 / $M E G A^{2}$ II.3.6, 2134.
} 
choose which capitalist in the singular will have the right to exploit the worker, results in the collective subjection of the working class to capital in general.51

The biting sarcasm with which Marx uses the notion of freedom finds its peak in the conclusion of the very section in which he introduces the "doubly free" wage laborer. First of all, he brutally scoffs at the liberal commentators' lofty view of the labor market. He directs his anger most of all at Jeremy Bentham, who translated political economy's celebration of the free agency and self-interest of the wage laborer into the realm of moral philosophy and contractual theory. The sphere of commodity exchange "within whose boundaries the sale and purchase of labour power goes on, is in fact a very Eden of the innate rights of man. There alone rule Freedom, Equality, Property and Bentham."52 However, Marx leaves no room for doubt that this is only a "vulgar" perception, which starts breaking down as soon as one leaves the separate sphere of circulation and enters the sphere of capitalist production. The imagery he uses, not coincidentally, is the same he employs when describing slavery: that of the acquisition of a person's skin.

He, who before was the money owner, now strides in front as capitalist; the possessor of labour power follows as his labourer. The one with an air of importance, smirking, intent on business; the other, timid and holding back, like one who is bringing his own hide to market and has nothing to expect but—a hiding. ${ }^{53}$

Here, the parallel with slavery is clearly symbolic. Nevertheless, there are other passages in which Marx goes considerably further, arguing that the sale of labor power under fully developed capitalism can under specific conditions approximate actual slavery. ${ }^{54}$ This does not take the racist form of describing all forms of (white) wage labor as worse than (black) slavery, as in the earlier

$5^{1} \quad$ This point is explored to great effect by Jacques Bidet, Exploring Marx's Capital. Philosophical, economic and political dimensions (Leiden and Boston, 2007), 27-51.

$5^{2} \quad M E C W$ 35, $186 / M E G A^{2}$ II.5, 128.

$53 M E C W$ 35, 186 / MEGA II.5, 128: In the German original: "Der ehemalige Geldbesitzer schreitet voran als Kapitalist, der Arbeitskraft Besitzer folgt ihm nach als sein Arbeiter; der Eine bedeutungsvoll schmunzelnd und geschäftseifrig, der Andre scheu, widerstrebsam, wie Jemand, der seine eigne Haut zu Markt getragen und nun nichts andres zu erwarten hat als die-Gerberei."

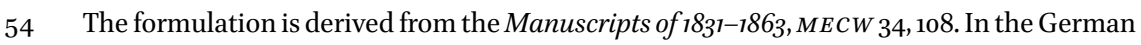
original, Marx uses the phrase "sinkt hier wieder annährend zum Sklavenverhältniss hinab." $M E G A^{2}$ II.3.6, 2144. 
remarks by Engels. ${ }^{55}$ Instead, Marx reserves the explicit comparison only for the most exploitative types of wage labor; the extension of the working day beyond the physically sustainable limit, and the hyper-exploitation of women and children. In both cases, Marx draws his comparisons from his readings on slavery in the United States. The first case was already mentioned in the introduction, and leads on to the sentences from which the title of this article is taken. In Chapter 3, Section 4 of Capital, dealing with the length of the working day, Marx intends to show that if not forced to accept some limits to exploitation, capitalist production tends to extend the working day to the point of risking killing the worker. In this, he argues, the capitalists behave like slave owners, who as long as the slave trade provided the influx of new "human chattel," valued an increase in productivity above the length of the life of the slaves. Quoting J.E. Cairnes's The Slave Power, Marx railed against the "reckless sacrifice" of the "Negroes' life" in order to obtain "fabulous wealth, that has engulfed millions of the African race." After summing up the ways in which slave lives were expended for the sake of profit, Marx makes his injection: "Mutato nomine de te fabula narratur!"56 explicitly claiming the validity of the example of slavery for the most oppressed sections of the working class.

Here, Marx is still clear that the comparison between slavery and wage labor is one between two fundamentally different phenomena (hence, "mutato nomine"). ${ }^{57}$ However, this changes when Marx comes to discuss the aspect of industrial exploitation that angered him most: The exploitation of child labor. ${ }^{58}$ The argument is noteworthy, because here Marx explicitly allows for the possibility that further capitalist development would partially dispense with even the limited form of freedom entailed in the "free" sale of labor power. Focusing on the role of the male heads of the family, who according to Marx were the ones who delivered their wives and children into the hands of the factory owners, he argues that in this case, the (female or child) laborers do not in fact freely sell their labor power at all:

55 In the Manuscripts of $1861-1863$, Marx still partially cited and partially paraphrased T.R. Edmonds, who argued that "the motive which impels a free man to labour is much more violent than the motive impelling a slave," $M E C W$ 34, 103n / MEGA ${ }^{2}$ II.3.6, 2137-2138, but this argument did not reappear in Capital.

$56 \quad M E C W 35,272 / M E G A^{2}$ II.5, 209.

57 In an earlier discussion of the same topic, included in the Manuscripts of $1861-1863$, this mark of distinction was absent. Here, Marx placed examples of the detrimental results of the extension of the working day on the life expectancy of wage laborers and slaves directly next to each other. $M E C W 3^{0}, 183 / M E G A^{2}$, II.3.1, 160 .

58 On Marx's bracketing of children's labor and women's labor in the passage discussed here, and the extent to which this stems from a gendered view of labor, see Heather A. Brown, Marx on gender and the family. A critical study (Leiden and Boston, 2012), 78-88. 
Taking the exchange of commodities as our basis, our first assumption was that capitalist and labourer met as free persons, as independent owners of commodities; the one possessing money and means of production, the other labour power. But now the capitalist buys children and young persons under age. Previously, the workman sold his own labour power, which he disposed of nominally as a free agent. Now he sells wife and child. He has become a slave-dealer. ${ }^{59}$

The theoretical importance can hardly be overstated. For in just a few lines, Marx emphasizes here that the representation of the meeting of capitalist and laborers as free persons was just a "first assumption," and acknowledges the possibility of "intermediary labor relations" in which labor power is sold on the market, but not sold by the laborer him- or herself. Furthermore, he does so with immediate reference to slavery. Just as in the case of the lengthening of the working day, Marx makes it clear that his comparison was not with slavery in the abstract, but with the form of slavery that had just been abolished under great acclaim in the Southern States of North America.

Die Nachfrage nach Kinderarbeit gleicht oft auch in der Form der Nachfrage nach Negersklaven, wie man sie in amerikanischen Zeitungsinseraten zu lesen gewohnt war.

[The demand for children's labor often resembles also in form the inquiries for Negro slaves, such as were formerly to be read among the advertisements in American journals. $]^{60}$

Neither was this equation of child labor with slavery accidental. Further on in Capital, Marx repeated it in his telegram-style summing up of the history of the cotton trade.$^{61} \mathrm{He}$ did so again in his discussion of original accumulation, following on the heels of his extensive denunciation of slavery under the Dutch in the East Indies. ${ }^{62}$ Bringing this history into the era of industrial capital, he emphasized "the necessity of child-stealing and child-slavery for the

\footnotetext{
$59 \quad M E C W$ 35, $399 / M E G A^{2}$ II.5, 324.

6o $M E C W 35,399 / M E G A^{2}$ II.5, 324. The English translation of Capital leaves out the crucial word "also" in "auch in der Form," which significantly changes its meaning, suggesting "in form rather than content," where Marx implies "both in form and in content."

$61 \quad M E C W$ 35, $458 /$ MEGA ${ }^{2}$ II. $5,371$.

62 "The treasures captured outside Europe by undisguised looting, enslavement, and murder, floated back to the mother-country and were there turned into capital. Holland, which first fully developed the colonial system, in 1648 stood already in the acme of its commercial greatness." MECW 35, 741 / MEGA2 II.5, 603-604.
} 
transformation of manufacturing exploitation into factory exploitation, and the establishment of the 'true relation' between capital and labour power." 63

Thus at the very moment that "free labor" in the classical liberal sense seemed to have gained its most significant historical breakthrough, Marx time and time again invoked the example of slavery to show this formal freedom to hide just one particular historical form of coerced labor. Further, in discussing the working day and child labor, he returned to the comparison at a greater level of concreteness in order to show that unless boundaries were enforced on it, capital's own logic impelled it to encroach on the distinction between slavery and wage labor; both in substance and in form.

\section{5 \\ Transitional Forms between Slavery and Capitalism}

In all the examples given in the previous section, Marx placed slavery next to "free" wage labor as a tool for comparison. Even when discussed using concrete examples to highlight actual historical conditions, rather than on the plane of abstract categories, slavery still mainly served the purpose of conceptual clarification. It helped Marx to draw out what was specific to the exploitation of labor by capital, without losing sight of the elements that bound it to all other forms of coerced labor across the world and throughout history. However, Marx was also acutely aware of the actual persistence of a slave sector within the nineteenth-century world economy, and its role in the expansion of the world market and industrial capital. We have seen that in 1847 , he summarized this in the pointed phrase: "without slavery no cotton, without cotton no modern industry." His sense of this mutual dependency was heightened by the sympathy for the slaveholding states expressed by important sections of the British industrial bourgeoisie during the American Civil War. This forced him to think about the historical relationship between slavery and capitalist development. Generations of Marxist historians have read Marx's reflections on this question primarily to obtain a set of solid definitions. The most important issue for them was whether in Marx's view, the commercial slavery of the American South and other regions presented a non-capitalist precursor or pedestal for "real" capitalist development outside of the capitalist system proper; a noncapitalist sector that functioned on the periphery of the capitalist world market, or was itself a form of capitalist production. ${ }^{64}$ Quotations from Marx can

$63 \quad M E C W$ 35, $745 / M E G A^{2}$ II.5, 605.

64 For different perspectives, see Eugene D. Genovese, "Marxian interpretations of the slave South," in Eugene D. Genovese, In red and black. Marxian explorations in Southern and 
be found for different, seemingly mutually exclusive positions. ${ }^{65}$ The attempt to elevate one of them to the status of "orthodoxy" runs counter to Marx's own searching, scholarly approach, an aspect of Marx's method that Marcel van der Linden has frequently emphasized.

Equally contentious is the question of whether, for Marx, the necessity of the dominance of wage labor for the development of full capitalism meant that all other forms of exploitation would exhibit a tendency to disappear. ${ }^{66}$ As Banaji notes, Marx's analysis explicitly excluded the possibility of "capital being founded on unfree labour (in the strict sense ...) at the level of the expansion of the total social capital." ${ }^{67}$ However, Marx also acknowledged the possibility of the existence of slavery at "individual points" within the "bourgeois system of production," albeit as an anomaly. ${ }^{68}$ His grappling with these questions should be understood in the context of his changing understanding of the origins, direction, and variants of capitalist development. In the introduction of Capital, Volume I, Marx could still insist that "the country that is more developed industrially only shows, to the less developed, the image of its own future." ${ }^{69}$ His later studies of agricultural change in Russia and India in particular would lead him to fundamentally reconsider this statement. ${ }^{70}$ Despite

Afro-American history (New York, 1968), 315-353; Robert Miles, Capitalism and unfree labour. Anomaly or necessity? (London and New York, 1987); Robin Blackburn, The making of New World Slavery. From the Baroque to the modern, 1492-180o (London and New York, 1997); Banaji, Theory as history; Charles Post, The American road to capitalism. Studies in class-structure, economic development and political conflict, 1620-1877 (Leiden and Boston, 2011). The third point of view has recently made a comeback in historiographical debate, although without explicit reference to Marx, in Sven Beckert, Empire of cotton. A global history (New York, 2014).

65 Cf., for example, the Grundrisse, MECW 28, 157 / MEGA ${ }^{2}$ II.1.1, 149, where he talks about "Negro slavery - a purely industrial form of slavery which in any case is incompatible with and disappears as a result of the development of bourgeois society," with the Manuscripts of 1861-1863, MECW 31, 516 / MEGA2 II.3.3, 936, where he states that in plantations "commercial speculations figure from the start and production is intended for the world market, the capitalist production exists, although only in a formal sense, since the slavery of Negroes precludes free wage labour, which is the basis of capitalist production. But the business in which slaves are used is conducted by capitalists. The mode of production which they introduce has not arisen out of slavery but is grafted on to it."

66 As suggested by Van der Linden, Workers, $19 n$.

67 Banaji, Theory as history, 142.

68 Marx, Grundrisse, MECW 28, 392 / MEGA II.1.2, 372. Cf. the Manuscripts of 1861-1863 where the same point is approached from the diametrically opposite angle: "But so long as slavery is predominant, the capital-relation can only be sporadic and subordinate, never dominant." MECW 33, 336 / MEGA2, II.3.5, 1851.

$69 \quad M E C W 35,9 / M E G A^{2}$ II.5, 12.

70 Anderson, Marx at the margins, 208-218; Tomba, Marx's temporalities, 170-186. 
this strongly linear sentence in the introduction of Capital, the seeds of a much more open approach had already been sown in the early 1860 . This is shown in a particularly striking way in a passage in the Manuscripts of 1861-1863, where Marx introduces the notion of "Uebergangsformen" (transitional forms):

I am ... speaking here of forms in which the capital-relation does not yet exist formally, i.e. under which labour is already exploited by capital before the latter has developed into the form of productive capital and labour itself has taken on the form of wage labour. Such forms are to be found in social formations which precede the bourgeois mode of production; on the other hand they constantly reproduce themselves within the latter and are in part reproduced by the latter itself. ${ }^{71}$

The notion of a "transitional form" does point towards a clear tendency for historical development (wage labor replacing slavery). However, the final sentence of the quotation also shows that in Marx's view, it was at least thinkable that capitalist development would never actually bring this tendency to completion. This opened up the intellectual space to discuss slavery not only as a stepping stone for capitalist development, but as a contemporaneous and connected phenomenon.

As a result of its preference for rigid definitions and clear demarcations, much of Marxist historiography has completely ignored the many areas of overlap, interaction, and combination between practices of exploitation and social struggle of "free" and unfree laborers. With regard to this neglect, Global Labor History launched an effective attack on the predominant mode of Marxist history writing. However, Marx himself was certainly not as unaware of the issue as many of his later followers were. Both his economic manuscripts and Capital contain extensive passages where he not only compares wage labor and slavery, but discusses the mutual historical influences and the relationships between the two. Rather than approaching slave production and capitalist production as two entities inhabiting their separate spheres, he attempted to show how their contemporaneity changed the mode of operation of both. For example, Marx discussed with considerable nuance the differences between forms of slavery in antiquity and in his own day, clearly differentiating between the nature of slave production, where this was primarily geared towards the production of use values, and slave production, where it operated for the market. Countering the Southern States' claims that slavery presented a patriarchal and therefore benevolent social system, Marx emphasized that

$71 \quad M E C W 34,117 / M E G A^{2}$ II.3.6, $215^{2}$. 
this might have been true in a very limited sense for an earlier period when it existed in relative isolation from capitalist markets, but not for modern slavery in its highly commercialized form:

In proportion, as the export of cotton became of vital interest to these states, the overworking of the Negro and sometimes the using up of his life in 7 years of labour became a factor in a calculated and calculating system. It was no longer a question of obtaining from him a certain quantity of useful products. It was now a question of production of surplus labour itself. ${ }^{72}$

Just as the nature of slave labor changed when it came under the indirect (through the market) or direct (through the ownership of plantations) control of the capitalist, so wage labor absorbed practices that had been developed in slavery. This is clearest in Marx's treatment of the role of superintendence or "labor for the exploitation of labor" in factory production. While Marx again does not let go of the fundamental distinction between wage labor and slavery, he stresses that the role of the supervisor in the factory is closer to that of the slave supervisor than to that of the master of the small workshops that dominated urban production in Europe before the Industrial Revolution. In the latter case, discipline was enforced through the master's own participation in the work process. By contrast, a sharp division of labor between the capitalist and the overseer would come to characterize the factory hierarchy. More than that of the workshop master, the "relations of subordination" and "regimentation" of the factory were a continuation of the relations between the "working Negro slaves" and the "slave-driving Negro slaves" on the plantation. ${ }^{73}$

Marx paid considerable attention to the results of the interaction and intermingling of various types of labor relations. This gave historical depth to his views on wage labor, feeding back into his conceptualizations of both exploited labor in general and the sale of labor power as the dominant basis of exploitation under capitalism. ${ }^{74}$ There was, however, an even more significant point where the sharp theoretical distinctions between historical phases broke down: The struggle for emancipation itself. This helps to explain why Marx's support for the Northern cause did not remain limited to his journalism and his political activity, but found a central place in his main theoretical work.

$72 \quad M E C W 35,244 / M E G A^{2}$ II. $5,182$.

73 In the Manuscripts of 1861-1863. MECW 33, 486 / MEGA2 II.3.6, 2019.

74 On the function of historicity in Marx's conceptualizations, see Derek Sayer, The violence of abstraction. The analytic foundations of historical materialism (Oxford, 1987), 126-130. 
Linking and comparing capitalism and slavery did not lead Marx to the racist perception of some sections of the workers' movement, that abolitionism was only a bourgeois distraction from the struggle of the (supposedly white) working class. Neither did it lead him back to his predictions from the $1840 \mathrm{os}$, that the development of the free market and the higher productivity of "free" labor would automatically destroy the social basis for slavery. Instead, by the time he wrote Capital, Marx had come to see the capitalist world market as thoroughly implicated in slavery, and the fight for slave emancipation as directly connected to the emancipation of the working class internationally. In his introduction to the first edition of Capital, Volume I, published only four years after Lincoln's Emancipation Proclamation, Marx expressed his expectation that the fall of slavery in North America would open a new round of social struggles internationally. "As in the 18th century, the American War of Independence sounded the tocsin for the European middle class, so in the 19th century, the American Civil War sounded it for the European working class." 75 Connected to this was his belief that Emancipation would usher in a progressive era of working class gains in the US itself:

In the United States of North America, every independent movement of the workers was paralysed so long as slavery disfigured a part of the Republic. Labour cannot emancipate itself in the white skin where in the black it is branded. But out of the death of slavery a new life at once arose. The first fruit of the Civil War was the eight hours' agitation, that ran with the seven-leagued boots of the locomotive from the Atlantic to the Pacific, from New England to California. ${ }^{76}$

In 1865, at the summit of Northern victory in the Civil War and in the midst of writing Capital, Marx's niece Nanette asked him about his personal heroes as part of a children's game. Marx' answers were Kepler and Spartacus; the astronomer who revolutionized Western science and the slave who emancipated himself to lead the largest slave revolt in antiquity. ${ }^{77}$ Taking a detour through distant European history, the answer symbolizes the emotional chords that bound Marx's scientific endeavors to his zeal for human emancipation from slavery—of every kind.

$75 \quad M E C W$ 35, $9 / M E G A^{2}$ II.5, 13.

$76 \quad M E C W 35,305 / M E G A^{2}$ II.5, 239-240.

77 Marx, "Confession," in Gielkens, Bommel, 155. 
Marcel van der Linden's reinterpretation of Global Labor History draws on a lifelong interest in the work of Marx. A central idea behind the project-the rejection of the association between capitalist development and the linear extension of "free" wage labor-is formulated as a critique of both classical liberalism and orthodox Marxism. However, it is clear that of the two strands of thought, it is the one that goes back to Marx that Van der Linden most fully engages with. The self-consciously heterodox approach provided by Van der Linden opens up major theoretical questions and has undoubtedly stimulated a whole new approach to the history of labor and labor movements. It has also provided room for critically re-examining established views on the writings of Marx himself. In this article, I have attempted to do the latter, focusing on the many passages in which Marx contrasts, compares, and draws historical connections between slavery and wage labor. Whereas Marxist historiography has mainly been interested in drawing sharp distinctions between the two, I have shown that Marx himself paid considerable attention to similarities, overlaps, and intermingling. This does not mean that Marx was a "Global Labor Historian" avant la lettre. For important theoretical reasons that I have outlined in the article, he continued to associate capitalist development with the increasing dominance of wage labor. However, a one-sided emphasis on this aspect alone has led many later writers to ignore important nuances in his treatment of the actual relation between wage labor and slavery.

Slavery holds a paradoxical place in Marx's intellectual development. In the early 1840 s, the young Marx had already turned to the working class, assigning to wage labor a central place both in capitalist development and in the struggle to overcome it. Between the first rough formulations of his economic theories in texts such as Wage Labour and Capital and the publication of Capital, Volume I, Marx would thoroughly reinterpret the main categories of classical political economy to put this connection on a firmer footing. At the same time, "free" labor seemed to make its most important global breakthrough of the nineteenth century with the abolition of serfdom in Russia and the emancipation of the slaves in North America. Marx could easily have taken this as confirmation of capitalism's inherent tendency to overcome all "antecedent" or "anomalous" forms of exploitation and subsume them under the aegis of wage labor. And yet he did not. On the contrary, nowhere in his writings was Marx so keen on comparing and connecting "free" wage labor and slavery as he was in Capital, Volume 1. The lengthening of the working day beyond the point where it could sustain the worker's life, could according to Marx be seen as slavery with only the name changed, and unrestricted child labor eroded 
even the formal freedom of the worker to such an extent that Marx was willing to describe it as slavery both in form and in content. As I have shown, these evocations of slavery were not simply rhetorical. They were instrumental in distinguishing Marx's conception of "free" wage labor from that of the classical liberal economists. In opposition to Adam Smith, John Stuart Mill, or Jeremy Bentham - but like Marcel van der Linden-Marx used the term "free" labor in a specific, highly conditional sense; as the designation of a particular type of coerced labor. In the immediate aftermath of the American Civil War, what could be a surer way of bringing home this point than showing the parallels and connections between wage labor and slavery?

Strong comparisons did not make Marx fall into the racist notion common among some sections of the workers movement that (white) wage labor in general was a form of slavery worse than actual (black) slavery. As the current article shows, the immediate background to Marx's frequent invocation of examples drawn from slavery was his growing intellectual, political, and emotional investment in the struggle against slavery in the Southern states of the U.S. The beginnings of this interest more or less coincided with his heightened attention to colonialism and the social upheavals that it produced. It led him to a much more concrete study of the actual functioning of slavery as a contemporary phenomenon, and to a more positive estimation of the potential agency of the slaves themselves. In the course of this, he largely abandoned his older mechanical conception that the development of the world market, combined with the greater efficiency of "free" labor over slavery, would be the lever for slave emancipation. Going beyond comparing slavery and wage labor as distinct historical phenomena belonging to separate phases of historical development, Marx acknowledged the contemporaneity of plantation slavery and capitalist development and reflected on the influence they had on each other. Perhaps most importantly, he increasingly drew a straight line between slave emancipation and working-class rebellion. Marx certainly continued to insist on the necessary relationship between capital and wage labor, but this did not blind him to the way capitalism drew upon and reproduced historically "transitional forms" of exploitation, or the role they could play in the struggles to come. 